\title{
Nová města a staří lidé
}

\author{
New cities and old people \\ Lucie Vidovićová, Eva Gregorová
}

\begin{abstract}
This article presents an overview of recent discussions on dynamic development in modern cities, namely revitalisation, gentrification and the regeneration of the built environment and its impact on the quality of life of older people living in these areas. We argue that these processes are highly normative and present themselves as primarily youthful phenomena. As such they may be considered a manifestation of age discrimination or even ageism, since older people seem to be more disadvantaged by urban revitalization and are at a higher risk of displacement. However, we need to gain more understanding of the mutual influence between ageing and environmental/urban change in general in order to pursue the building of an (age) inclusive society.
\end{abstract}

KEY WORDS ageing, gentrification, older people, revitalisation, social exclusion

\section{Úvod}

Populační stárnutí a urbanizace jsou dva globální trendy, které představují nejvýznamnější síly formující 21. století (Global... 2007). Zejména v českém kontextu byla ovšem doposud věnována jen minimální pozornost vzájemným souvislostem těchto dvou fenoménů - tedy problematice starších lidí v městském prostoru a naopak významu městského prostoru pro konstrukci zkušenosti stárnutí.

V ČR žije ve městech $73 \%$ populace, v případě seniorů je míra urbanizace dokonce ještě o něco vyšší - ve městech žije 75 \% všech osob starších 60 let. (Zdroj: ČSÚ: 401908ri02). Můžeme se domnívat, že oba tyto podíly se budou do budoucna ještě zvyšovat s tím, jak se bude česká společnost přibližovat demografickým a sociálně-geografickým profilům EU-15. Významnou roli zde hraje fakt, že česká populace obecně se vyznačuje relativně malou prostorovou mobilitou (Mikeszová, n.a.). Ta se ve vyšším věku ještě dále snižuje s tím, jak mizí tradiční důvody pro změnu bydliště (Sochůrková 2006; Sunega 2001). Podle dostupných

Sociální studia. Fakulta sociálních studií Masarykovy univerzity, 3/2010. S. 81-93. ISSN 1214-813X.

1 Autorky děkují dvěma anonymním recenzentům a editorskému týmu za jejich významné připomínky, jež přispěly $\mathrm{k}$ celkovému přepracování textu. Text vznikl s podporou Institutu pro výzkum reprodukce a integrace společnosti Fakulty sociálních studií Masarykovy univerzity (MSM0021622408) a projektu „Stáří v prostoru: regenerace, gentrifikace a sociální exkluze jako nové problémy environmentální gerontologie“ (GAČR, č. grantu P404/10/1555). K projektu viz též http://starnuti.fss.muni.cz. 
šetření bydlí čeští senioři nad 60 let ve svých bytech v průměru 30 let (modus 40 let), a o přestěhování v blízké budoucnosti neuvažuje 79 \% z dotázaných seniorů (Kuchařová 2002). Navíc většinu svého času, zahraniční studie odhadují 70 až 90 procent (Baltes, Baltes 1990), senioři tráví v bezprostřední blízkosti svého bydliště. Na základě těchto zjištění můžeme tvrdit, že většina lidí (ze)stárne v místě, kde prožila velký díl svého produktivního života, a pro většinu českých seniorů proto je a bude tímto „místem“ prostor urbanizovaný - město.

Budeme-li chtít hovořit o vzájemných souvislostech populačního stárnutí a životní zkušenosti žité ve městě, jak bychom si mohli urbánnost předběžně „operacionalizovat“ pro náš kontext, musíme podtrhnout multidimenzionálnost obou těchto jevů. Senioři patří k nejvíce heterogenním sociálně definovatelným skupinám populace. Odhlédneme-li od základních dvou kategorií, tj. pohlaví a věkového rozptylu 40 až 45 let v závislosti na zvolené administrativně-statistické hranici stáŕí, jsou senioři velmi různí, v různém stupni funkčního zdraví, s různým socio-ekonomickým statusem, s různými potřebami a preferencemi, což se odráží i do forem jejich bydlení a užívání fyzického prostoru. Na druhé straně máme obecně chápaný městský prostor, jehož význam může variovat podle lidnatosti a velikosti místa našeho zájmu (celek, městské části, domovní bloky apod.), jeho geografické polohy i sociálně-kulturních a demografických charakteristik. Oba dva koncepty jsou přitom ze své podstaty dynamické a ve svém obsahu sociálně konstruovatelné. A právě interference mezi těmito dvěma, do jisté míry fluidními koncepty se stala výchozím bodem našeho zájmu.

Jednání a chování lidí je prakticky neoddělitelné od jejich prostředí či místního kontextu (Wapner 1987). Prakticky vše, co se děje, se děje „někde“, a místo a čas variují podle trvání, pravidelnosti a frekvence takového jednání. I na obecné rovině tedy máme co dočinění s reciproční konstrukcí (symbolického) významu prostoru. „Jedinci, kteří vstoupí do nového prostředí anebo modifikují prostředí existující, nevyhnutelně změní (přidají, opustí nebo upraví) své každodenní rutiny a aktivity“ (Golant 2003: 644). Jinými slovy, prostředí a jeho změna má velký potenciál pro ovlivnění každodennosti a naopak „,výkon každodennosti“ ovlivňuje životní prostředí aktéra. Tento vztah se zdá platit ještě silněji ve vyšším věku, kdy akční rádius aktéra má tendenci se prakticky i symbolicky smrštovat a přibližovat se $\mathrm{k}$ jádru tvořenému intimním prostorem stárnoucího jedince (Sýkorová 2008). Hovoříme-li zde o jádru, vycházíme z ilustrace životních prostředí jako modelu složeného ze soustavy soustředných kružnic kolem jednice, počínajících na mikro rovině prostoru pokoje a bytu, pokračující přes sousedství, město/obec, regiony až na makro úroveň národních států a nadnárodních celků. Jak ukazuje např́ílad šetření European Value Study 1991 - 2008, existuje souvislost mezi věkem respondenta a velikostí geografického celku, ke kterému cítí respondent nejvyšší sounáležitost. I když mezi sledovanými lety roste odklon od pocitu sounáležitosti s většími celky ve prospěch menších geografických celků obecně, je pocit náležitosti k obci (místu, kde žije) tím silnější, čím je respondent starší (Gregorová, Vidovićová, Karchňáková 2010).² Máme tedy za to, že případné změny na této mezo úrovni jsou přinejmenším stejně závažného

2 Př́slušnost $\mathrm{k}$ místu, obci, kde žije, v roce 2008 vyjádřilo $55 \%$ respondentů do 30 let, ale již téměř $67 \%$ respondentů starších 60 let. Naopak příslušnost $\mathrm{k}$ České republice vyjádřilo více mladých (28\%) než seniorů (20\%). Obdobně v př́padě varianty „sounáležitost ke světu jako celku“ byl podíl juniorů oproti seniorům dvojnásobný (4\% vs. 2\%) (Gregorová, Vidovićová, Karchňáková 2010). 
charakteru pro tvorbu zkušenosti stárnutí, jako již dobře dokumentované souvislosti mezi kvalitou života ve stáríí a mikro prostředím. ${ }^{3} \mathrm{~V}$ české gerontosociologii však této vyšší úrovni, tedy životnímu prostředí definovanému jako sousedství a/nebo město/obec, kde senior žije, bylo doposud věnováno jen minimum pozornosti. Přitom právě tato geografická či teritoriální úroveň je jednou z nejvýznamnějších a nejilustrativnějších platforem dynamických změn (post)moderních společností (Giddens 1999).

Smith (2009) se ve své publikaci „Ageing in Urban Neighbourhoods“ (Stárnutí v městském prostředí) snažila shrnout základní charakteristiky měst, a zejména jejich centrálních částí, ${ }^{4}$ které mohou vytvářet specifické životní podmínky pro jejich stárnoucí obyvatele a tím, at' už príímo nebo neprímo, ovlivňovat jejich kvalitu života. Přestože, anebo právě proto že městské prostředí je ze své podstaty hodnoceno ambivalentně (pro základní přehled diskuse viz např. již výše citovaný Giddens 1999), lze i jeho charakteristiky rozdělit na ,pro-seniorské“, tedy podporující dobré stárnutí (,,ageing well“"), a charakteristiky, které naopak kvalitu života ve vyšším věku ohrožují, snižují.

Mezi znaky podporující dobré stárnutí Smith (2009) zařadila vy̌šś hustotu obyvatelstva a lepší dostupnost služeb a obchodů, které pomáhají uspokojit základní potřeby každodenního života. V důsledku toho, tvrdí autorka, je posilován i pocit sounáležitosti k místu či vy̌šśí občanská angažovanost v místní komunitě. Služby jsou navíc v městských centrech obvykle dostupné ve větší variabilitě a mohou tak podporovat různorodost heterogenních životních stylů seniorů. Nezř́́dka je ovšem paleta služeb filtrována ekonomickými podmínkami seniorů a jejich dostupnost tak může být (paradoxně) omezena pro seniory ohrožené sociální exkluzí (Scharf, Phillipson, Smith 2005). Podobně ambivalentní dopad na městská prostředí a seniory v nich má i globalizace. Phillipson (2007) hovoří o diverzitě sociálních, kulturních a ekonomických městských sfér, které globalizace vytváŕí, a které pak slouží jako podloží pro vytváření nových typů „hnutí“ ve vyšším věku. ${ }^{6}$ Pozitivní dopady těchto změn ale sledujeme spíše jen u těch, jak dodává zmiňovaný autor, kteří jsou, zejména díky svému zdraví a finančním možnostem, schopni se přizpůsobit a na změny nesené globalizací adekvátně reagovat. Pro ty ostatní, kteří nedokážou nebo nemohou „zúročit“ globalizační změny, spíše než maximalizaci

3 Hojně citovaným př́kladem je např. studie „Living and Dying at Murray Manor“ (Gubrium 1997), která prokazuje, že prostor (tj. pokoje, podlaží, kanceláře) zásadním způsobem určuje světy interakce klientů a personálu, a tím formuje světy významů žití jedinců. Pro další př́klady viz Levy (2003), Bell et al. (2001), Oswald (2007) aj. V českém prostředí a kontextu autonomie se tématem pionýrsky zabývala Sýkorová $(2007,2008)$.

4 Také v České republice patří centrální části měst $\mathrm{k}$ těm populačně nejstarším. Na př́ikladu Prahy to detailně ilustrovala např. Dvořáková (2008), na př́ikladu Brna a Ostravy Vaishar et al. (2009).

5 Svůj specifický prŕstup k definici věku-přátelských měst má Světová zdravotnická organizace. Ta definovala osm kategorií, na základě kterých by mělo být možné města hodnotit. Kategorie definované $\mathrm{v}$ tomto konceptu jsou relativně široké a jejich detailní operacionalizace představuje téměř neřešitelný úkol. Na druhou stranu jsou ale dobrým ukazatelem komplexity charakteristik městského prostředí, které mají prř́mý vliv na dobré stárnutí. Patří sem bydlení, sociální participace, respekt a sociální inkluze, občanská angažovanost a zaměstnání, komunikace a informace, komunitní podpora a zdravotní služby, venkovní prostředí a budovy, a konečně doprava (Global ... 2007).

6 Gilleard a Higgs (2000) hovoří o nových kulturách, či třídách. K diskusi o nových věkových tř̌idách též v české společnosti viz Vidovićová (2008). 
blahobytu, představují globalizační změny nárůst rizik a destabilizaci. Globalizace tak produkuje nové sociální nerovnosti mezi těmi, „kteří si mohou vybrat místo bydliště v souladu se svými biografiemi a životními historiemi, a těmi, kteří ve svém prostředí zakoušejí odmítnutí a marginalizaci“ (Phillipson 2007: 321).

\section{Revitalizační změny jako možné zdroje exkluze ve stáří}

Taková rizika pro dobré stárnutí v městském prostředí však zdaleka neplynou jen z globalizačních trendů. Řada ohrožení má naopak velmi konkrétní, často až fyzickou podobu. Smith (2009) vyjmenovává např. problém přelidnění, hluk, znečištění, dopravní zácpy, nekvalitní povrchy pro pěší, nedostatek odpočinkových míst či veřejných toalet, obavy z kriminality, vyšší výskyt sociálně patologického chování, (ne)dostupnost služeb vyšší kvality nebo celková (ne)estetičnost prostoru. Všechny tyto faktory se aktivně podílejí na konstrukci životní zkušenosti stárnutí vázané na fyzický prostor. Jedná se ovšem o charakteristiky, které jsou již z velké většiny produktem určitých, sociálně-ekonomicko-kulturních a environmentálních změn, které mají ve svém důsledku také zpětný dopad na demografii jednotlivých území či geografických celkủ. ${ }^{7}$ Tyto zdrojové změny prostředí mohou nabývat různých forem, mohou mít různé příčiny a důsledky (které často mohou vzájemně splývat), odlišné hybatele, „vítěze“ a „poražené“. V daném rozsahu tohoto textu není možné tyto systémy komplexně vysvětlit, ba dokonce ani popsat. Zvolili jsme proto jen jeden př́klad dynamické a komplexní proměny fyzického prostředí, který lze považovat za charakteristického zástupce (post)moderních změn $\mathrm{v}$ současných městech $\mathrm{s}$ př́mým dopadem na seniorskou populaci. Jedná se o revitalizaci a zejména její specifické sub-formáty: regeneraci a gentrifikaci. Regeneraci a gentrifikaci lze považovat za zdroj proměny fyzického prostředí, který ve svém důsledku mění nejen prostředí „neživotné“, ale i okolí „životné“, sociální. V následujícím oddíle se proto zaměríme na význam těchto revitalizačních a gentrifikačních změn pro seniorskou populaci žijící ve městech. Vzhledem k tomu, že zatím nemáme k dispozici odpovídající data pro Českou republiku, reprodukujeme zde především argumenty několika málo zahraničních výzkumů, které byly tomuto tématu věnovány. Nejdřive si ovšem tyto základní pojmy definujme.

Šilhánková (2000: 3) rozlišuje šest různých typů procesů revitalizace fyzického prostředí: modernizaci, gentrifikaci, regeneraci, dostavbu, přstavbu a asanaci. Zatímco všechny tyto typy souvisí s prostorovou (fyzickou) přeměnou lokality, ekonomickou a sociální „obnovu“ v sobě zahrnuje především regenerace a gentrifikace. ${ }^{8}$ Regenerace je u stejné

7 Z logiky našeho uvažování o duální konstrukci těchto fenoménů platí, že demografické charakteristiky také zpětně ovlivňují environmentální celky. Vyslovujeme hypotézu, že populačně starší území, bez ohledu jak pojem území definujeme, se od těch mladších budou, přinejmenším do budoucna, lišit v takových oblastech, jako je např. organizace zajištění sociální péče, typ bytové zástavby, definované politické priority apod. Již dnes bychom mohli takové rozdíly očekávat např. mezi centry měst (např. index stáŕí MČ Praha $1=149$ ) a výrazně mladšími suburbánními oblastmi (např. Praha-západ má index stáří o více než polovinu nižší, tj.71; Zdroj: ČSÚ).

8 Podle definice bychom do této podskupiny mohli zařadit i asanaci, tj. extrémní př́pad totální výměny jak fyzického, tak i sociálního prostředí. Pro ilustraci našeho zájmu se však omezíme pouze na regeneraci a gentrifikaci. 
autorky definována jako „obnova a údržba existujících struktur stavebního fondu, která si klade za cíl dosažení soudobých standardů ...ve starší zástavbě ...[a] je spojena s očištěním struktury od nevhodných součástí a nevhodných způsobů využití a nalezení vhodného soudobého funkčního využití.“ (ibid.) Obdobně se gentrifikací rozumí proces, „při němž dochází k rehabilitaci obytného prostředí některých čtvrtí a postupnému vytlačování a nahrazování původního obyvatelstva př́ijmově silnějšími vrstvami. Při tomto procesu dochází ke změně sociálního charakteru a zlepšení sociálního fyzického stavu lokality“ (Šilhánková 2000: 3, kurzíva v obou citacích LV, EG). Gentrifikaci, ale v zásadě i důsledky regenerace, můžeme podrobněji popsat těmito vzájemně provázanými kroky: v určitém časově omezeném období a fyzicky vymezitelném prostoru jedna skupina obyvatel s vyšším sociálním statusem nahradí jinou skupinu původního obyvatelstva; mění se bytový fond, dochází k celkové estetizaci prostředí (včetně veřejných prostranství) a rozšiřuje se a zvyšuje se kvalita služeb; dochází ke koncentraci obyvatel, u nichž lze předpokládat shodné kulturní vzorce a životní styl, popríípadě alespoň příbuzné konzumní preference; dochází k ekonomické obnově a zhodnocení majetku a současně $\mathrm{k}$ rozšíření soukromého vlastnictví v systému bytového fondu (Burjanek 1995); komunita původních obyvatel se rozpadá; část původního obyvatelstva je vytlačena vysokými náklady na bydlení z lokality pryč, část zůstává a snaží se nové situaci přizpůsobit. U obou těchto skupin původního obyvatelstva se zvyšuje riziko jejich sociálního vyloučení. Z logiky definice jsou regenerační a zejména pak gentrifikační proměny projevem třídní nerovnosti. $V$ původním významu pojmu se jedná především o procesy tř́inního následnictví v oblastech původně osídlených „,pracujícími“ a nižšími sociálními trí́dami (Smith, Williams 1986; Zukin 1987; Butler 2005; Sýkora 2005). Později jsou tyto pojmy používány obecněji pro popis infiltrace vyšší kultury (třídy) do oblasti původně specifické pro kulturu (tř́́du) nižší (Thompson 1999, ABZ Slovník... n.a.). V tomto rozšířeném pojetí pak můžeme hovořit i o tzv. třídách věkových (Chudacoff 1989; Vidovićová 2008), a o pronikání mladých lidí do prostoru (tradičně) „osídleného“ staršími lidmi. ${ }^{10}$

Tato rétorika třídní nerovnosti odráži fakt, že skupina nově prríchozích obyvatel je relativně homogenní: jedná se především o lidi mladší, s vyšším vzděláním a socioekonomickým statusem. Oproti tomu bývá vykreslený obrázek původního obyvatelstva mnohem barvitější a méně jednoznačný. A to zejména tehdy, je-li snahou popsat osoby nejvíce negativně postižené revitalizací, tj. osoby z původních oblastí vysídlené (angl. displaced). ${ }^{11}$ Uvádí se, že

9 Název tohoto fenoménu je odvozen od angl. „gentry“, tedy „panstvo“. Poprvé byl pojmenován Glass (1964), která hovořila o invazivní výměně obyvatelstva v Londýnské čtvrti East End v šedesátých letech 20. století.

10 Na př́kladu stěhování mladých lidí do komercionalizovaných oblastí s vysokým podílem seniorské populace v rámci vnitřní Prahy to v českém kontextu ukázala již citovaná Dvořáková (2008). K proměnám fyzického prostoru viz Temelová (2006).

11 Informace o vymístěných osobách se v severoamerických studiích obvykle opírají o kvantitativní rozdíly ve složení populace daného území mezi jednotlivými cenzy. Atkinson (2000: 163) přirovnává tyto pokusy k „měření neviditelného“, protože je velice obtížné zjistit osudy vymístěných a tím de facto potvrdit jejich status vymístěných oproti napřs. přirozené měně. Newman a Wyly (2006: 31) ale argumentují, že nelze na tyto snahy rezignovat, nebot' „i když se vymístění týká velmi malého podílu domácností, nemůže být považováno za nevýznamné. Deset tisíc vymístěných každý rok 
mezi vymístěnými jsou obvykle nadreprezentováni cizinci (resp. etnické minority), domácnosti, jejichž přednostou je žena, domácnosti pod hranicí chudoby, jednočlenné domácnosti, a ty ze starších věkových skupin (Henig 1981; Singelakis 1990; Newman, Wyly 2006; Chui 2008). V kontrastu k nově přistěhovaným tak tvoří relativně heterogenní skupinu. Navíc řada zde vyjmenovaných charakteristik má tendenci se vyskytovat společně, vzájemně tak posilovat marginální status jedince, a vystavovat jej kombinovaným rizikům sociálního vyloučení. Na revitalizaci je proto nutné nahlížet také jako na ambivalentní proces prostorové a sociální diferenciace, která nerovnoměrně zasahuje různé sociální skupiny a která produkuje či dále prohlubuje ohrožení sociální exkluzí.

Newman a Wyly (2006) shrnují, že vymístění vyskytující se v př́mé souvislosti s gentrifikací a regenerací (resp. obecně revitalizací) může nastat $v$ důsledku demolice domů, změny vlastníků obytných/nájemních jednotek, zvýšených nákladů na bydlení (nájmů a daní z nemovitostí), obtěžování ze strany nových nájemců/vlastníků a výpovědi z bytu. Spolu s vymístěnými osobami mizí i důležité komunitní sítě a kultura místa obecně, což představuje znevýhodnění i pro ty jedince, kterým se jinak podařilo „ustát“ tyto př́mé tlaky a participovat na výhodách plynoucích ze zlepšeného životního prostředí v sousedství. Neyden et al (2006) rozšiřují seznam negativní důsledků specifických revitalizačních proměn na původní obyvatele o růst životních nákladů, nemožnost dovolit si nakupovat v nových exkluzivních obchodech a využívat nové služby, o obtěžující tlak realitních makléřů, nesdílení nových kulturních a životních vzorců, ztrátu kořenů a již zmiňovanou ztrátu původního charakteru místa. ${ }^{12}$

Tyto negativní průvodní jevy obnovy fyzického prostředí jsou obzvláště závažné pro osoby ve vyšším věku. Ty jsou obvykle na své (dlouhodobé) bydliště více vázáni než lidé mladší (Steinführer 2003), a př́ípadná nutnost vystěhování pro ně představuje vyšší finanční, sociální i emoční náklady (Fokkema et al. 1996; Henig 1981). Hluboké a zásadní proměny, jež jsou zpravidla dlouhodobějš́ího charakteru a jsou vůči rezidentům vnější, nemá senior možnost aktivně ovlivnit ani co do jejich podoby, ani co do jejich směru či trvání. Dochází tak k ohrožení tzv. „environmentální proaktivity“, tj. schopnosti starších osob uspořádat svoji (bytovou) situaci v souladu se svými potřebami a cíly (Lawton 1989, Oswald et al. 2003). V konečném důsledku tak může dojít $\mathrm{k}$ vymístění i bez faktického opuštění fyzického místa. Pro zkušenost tohoto typu vymístění, která s sebou nese velká psychická i sociální rizika, je dostačující ztráta důvěrně známého prostředí bytu, domu, sousedství a věcí, které staří lidé potřebují, jež definuji jejich osobnost a činí život smysluplným (Douglas 1991). Někteří senioři své sebe-pojetí odvozují od své minulosti, minulých zkušeností a chování, od svých

by nemělo být ignorováno, dokonce ani v osmimilionovém městě.“ Podle jejich výpočtů vymístění v rámci města New York představuje 6 až $10 \%$ všech stěhování v nájemních bytech ročně.

12 Zároveň ale stejní autoři upozorňují i na možné pozitivní důsledky gentrifikace, ze kterých mohou těžit i původní obyvatelé ze sociálně vyloučených skupin. Jsou to např́íklad estetizace prostředí, nová veřejná prostranství, více zeleně, větší možnosti pro podnikání, tj. zvýšení zaměstnanosti v oblasti, větší nabídka služeb, větší bezpečnost (menší kriminalita), čistota a pořádek. Jiní ale oponují, že např́íklad otázka snížení kriminality v gentrifikovaných oblastech není jednoznačně vyřešena. McDonald (1986) zjistil, že úleva od kriminality v gentrifikovaných oblastech může být pouze dočasná, a míry majetkové kriminality dokonce nebyly v jím zkoumaných oblastech nijak významně dotčeny. 
kořenů. $\mathrm{V}$ takovém prŕípadě může být zážitek přestěhování obzvláště traumatizující, a to bez ohledu na objektivní kvality nového prostředí. V novém místě se totiž takový senior cítí jako cizinec bez historie, což může vést k pocitům stresu, obav a ztráty kontroly nad svým životem a/nebo prostředím (Golant 2003). Zážitek vystěhování ale není nutně v silně heterogenní skupině seniorů zážitkem s univerzální náplní. Např́klad Redfoot (1987) na vzorku čtyřiceti žen $\mathrm{z}$ různých sociálních trríd zjistil, že ženy z nižších sociálních tříd se ve svém životě často stěhovaly a s velkou pravděpodobností nebyly vlastníkem svého bydlení. Proto braly každé další stěhování, $v$ tomto prríkladě do instituce pro seniory, jako další v řadě, a jiné pouze $\mathrm{v}$ tom, že bylo provázeno větším pohodlím a bezpečím. Oproti tomu ženy z vyšších sociálních tříd, které byly častěji vlastnicemi svých domů či bytů a žily v nich velmi dlouho, měly velmi silný pocit sounáležitosti s místem, které opouštěly. V institucionálním bydlení pak měly tendenci vytvářet jakási muzea svých životů a byly nuceny hledat další adaptivní mechanismy na tuto environmentální změnu.

Očekávání, že senioři trpí vymístěním v důsledku gentrifikace více než jiné věkové skupiny, je založeno na předpokladu, že starší lidé jsou více závislí na stabilním a předvídatelném prostředí a tento předpoklad staví na třech argumentech - fyzickém, sociálním a ekonomickém (Henig 1981). Prvním argumentem jsou fyzi(ologi)cké změny provázející stárnutí, jako může být zhoršující se zrak a sluch nebo prodlužující se reakční doba. Tato fyzická omezení mohou zhoršovat schopnost přizpůsobit se změnám v okolí, snížit kapacitu pro adaptaci a vyrovnat se se stresem. Neschopnost dostatečné adaptace na nové prostředí může být mylně považována za projev demence a vést $\mathrm{k}$ neúměrné stigmatizaci či medikaci, apod. Druhá množina argumentů se týká sociálních nákladů vymístění. Přátelé a sousedé jsou součástí podpůrného systému, na který řada seniorů spoléhá při vykonávání každodenních činností, jako jsou nákupy a další drobné služby. ${ }^{13}$ Vymístění pochopitelně tyto vazby ohrožuje a sociální izolace, do které se senior může v novém bydlišti dostat, pak může být zdrojem řady patologií, od depresí po zvýšenou míru sebevražednosti ve vysokém věku. ${ }^{14}$ Nezanedbatelné jsou do třetice i náklady finanční, počínaje od nákladů na stěhování a agendu se změnou adresy, až po velmi pravděpodobné zvýšení nájmu oproti (původnímu) nájemnému v bývalém bydlišti. Mezi náklady můžeme přitom řadit i ohrožení zdraví a blahobytu seniorů. Jak ukazují některé studie, které se ovšem zaměřovaly především na problematiku přesídlení

13 Podporu od sousedů a přátel při zajištění svého života ve stáří očekává 29 \% seniorů nad 60 let, což tuto skupinu staví na druhou pozici za vlastními dětmi a před dalšími př́ibuznými a dokonce před pomocí institucionální (Kuchařová 2002:7). Sousedé jsou také zdrojem očekávané pomoci při péči v nemoci a potřebě výpomoci s domácími pracemi pro zhruba $7 \%$ respondentů starších 50 let (Survey 50+, Nešporová et al. 2008).

14 Stárnutí v místě a rezidenční kontinuita jsou obecně považovány za velmi prospěšné a žádoucí. Existují nicméně i př́iklady, kdy je naopak určitá environmentální změna ve svých dopadech žádoucí a pozitivní. Taková změna je obvykle charakterizována vlastní iniciativou seniora, je jím „kontrolována“ a je jím samotným vnímána jako cesta k zajištění lepší budoucnosti (Golant 2003). Typickým př́ikladem je nástup výrazné disability, kdy senior může uvítat a iniciovat přesun do prostředí, které bude lépe vyhovovat jeho omezeným funkčním schopnostem a zajistí tak jeho větší bezpečí a lepší péči. Přestěhování může v některých prrípadech seniory také ochránit od abuzivních a agresivních osob a vztahů v okolí. 
z domova do rezidenční péče (Redfoot 1987 aj.), změna bydliště ve vyšším věku může negativně ovlivnit úroveň fyzického i duševního zdraví, životní spokojenost a dokonce i mortalitu, a to zejména - jako je tomu právě často $\mathrm{v}$ př́padě gentrifikace - je-li podnět k přestěhování mimo jedincovu plnou kontrolu (Henig 1981).

Nyden et al. (2006) však upozorňují, že věk samotný je nedostatečnou podmínkou pro riziko vymístění, protože mezi novými obyvateli luxusních bytů a kondominií v gentrifikovaných oblastech jsou nezř́́dka i osoby starší 65 let. Problémem jsou spíše tzv. zdvojená či vícenásobná rizika (Vidovićová 2008), tedy kombinace (vy̌ššho) věku a dalších znevýhodňujících faktorů, typicky pohlaví, etnicity, nižšího socioekonomického statusu či disability. Newman a Wyly (2006) testovali regresní model zahrnující charakteristiky vymístěných v New Yorku a zjistili, že vedle očekávatelných socio-demograficko-ekonomických charakteristik hrály důležitou roli i kontextuální proměnné, jako je cena bydlení v lokalitě a jeho kvalita. Nájemníci žijící v levnějších, méně kvalitních a významně přelidněných domech a bytech měli větší riziko vymístění, stejně jako lidé méně spokojení s kvalitou bytového fondu v sousedství. Charakteristiky, které je možné shrnout pod název „špatná vs. dobrá adresa" přitom hrály statisticky nejvýznamnější roli, ale explanační síla zmiňovaných charakteristik mezi jednotlivými lety zkoumání variovala. V této citované studii Newman a Wylyho (2006) pouze jeden $\mathrm{z}$ patnácti sociálně slabších nájemců $\mathrm{v}$ dané oblasti bydlel $\mathrm{v}$ bytě $\mathrm{s}$ tržním nájemným. Má se za to, že regulované nájemné do určité míry zmírňuje tlak na vymístění a může přispívat $\mathrm{k}$ pozitivnějšímu hodnocení revitalizačních procesů. Oproti tomu proces deregulace nájemného, jak jsme ho svědky v současné době, slouží jako další rizikový faktor pro vymístění seniorů (Mikeszová, Lux, Morisseau 2009). Vedle individuálních charakteristik seniorské populace tak musíme při hodnocení procesů, někde nazývaných jako nová kolonizace (Atkinson, Bridge 2005), uvažovat o kontextuálních souvislostech a relevantních politikách a jejich specifickém dopadu na seniorskou populaci.

Lidé zachycení $\mathrm{v}$ procesu gentrifikace a regenerace mají $\mathrm{k}$ dispozici několik strategií, které jim umožňují v těchto oblastech zůstat. Regulované nájemné, spolu se sociálním bydlením, obecními byty, chráněným bydlením a různými formami sociální pomoci představují nejběžnějši formy institucionální ochrany. Mezi individuální strategie se pak řadí smírení se s nižší kvalitou bydlení, zvládání zátěže vysokých nákladů na bydlení nebo sdílení bydlení $\mathrm{s}$ dalšími osobami, sestěhování se s dětmi, př́buznými, práteli apod. ${ }^{15}$ Existují také komunitní hodnoty a soudržnost, které tlaky trhu zmírňují. Např́klad dlouhodobí nájemci mohou mít se svým majitelem natolik dobré vztahy, že ten se pak neř́dí striktní logikou trhu a nájmy svým nájemníkům zvedá v únosné míře. To jsou ovšem velice chabé pojistky, které také nezř́́dka selhávají, a to zejména $\mathrm{v}$ př́ípadech, kdy je až př́liš velký rozdíl mezi tržním nájemným v okolí, majitel domu zemře nebo dům prodá apod. Za nejspolehlivější ochranu před dopady gentrifikace je proto obvykle považováno vlastnické bydlení. Ani to však není univerzální

15 Sdílené bydlení je ale považováno za nejméně žádoucí formu bydlení ve vyšším věku (Vidovićová, Rabušic 2003; Nešporová et al. 2008). Můžeme tedy vyslovit hypotézu, že strategie uvedené v tomto výčtu nevedou k zachování původní kvality života. Podobně jako v případě vymístění, stejně i při setrvání v gentrifikovaných oblastech se předpokládá aktivace silných adaptivních mechanismů, což, jak jsme uvedli i výše, má v případě staršího člověk svoji, obvykle nemalou cenu. 
ochrana. S tím, jak rostou ceny nemovitostí, rostou také daně z nich odváděné, což může být problém především pro starší vlastníky, kteří jsou závislí na fixních příjmech z důchodového systému (Newman, Wyly 2006). A takových je v českém prostředí většina. Na důchodové dávce ze sociálního systému jako jediném zdroji př́ijmu je závislých téměř $96 \%$ populace starší 60 let (Kuchařová 2002). Přitom téměř $73 \%$ české populace starší 50 let jsou vlastníky domů (48 \%) nebo bytů ( $25 \%$ ), ve kterých bydlí (Bydlení 2008), a musí z těchto omezených příjmů vykrýt zvyšující se přímé i nepřímé náklady na vlastnické bydlení. Již dnes jsou výdaje na bydlení v seniorských domácnostech vyjádřené jako podíl na př́ijmech oproti domácnostem až dvojnásobné. Podle dat ze Statistiky rodinných účtů (ČSÚ 2008) vydá seniorská domácnost až třetinu své spotřeby právě na bydlení a s ním spojené náklady na údržbu a vybavení. S rostoucím věkem a rizikem ovdovění (tj. u jednočlenných domácností) navíc také klesá schopnost si např. údržbu zajistit svépomocí. U seniorů v nájemním bydlení, kterých je asi $15 \%$ (10\% v obecních/státních a $5 \%$ v soukromých bytech), je hlavní finanční zátěž koncentrována do samotného nájmu. Obavy z jeho zvyšování mají tři čtvrtiny nájemníků u soukromých vlastníků, a dokonce $85 \%$ nájemníků v bytech obecních, státních či podnikových (Bydlení 2008, vlastní výpočty). Rozhodně či spíše dostatek finančních prostředků na bydlení tak deklaruje pouze 57 \% seniorů nad 60 let (Kuchařová 2002). Můžeme se proto domnívat, že další zvýšení nákladů na bydlení v důsledku, byt' snad dobře míněné, revitalizace jejich životního prostředí, může pro řadu seniorů představovat významnou zátěž i v českém kontextu. Jak uvádí Newman a Wyly (2006), starousedlíci totiž intenzivně vnímají onu inherentní ambivalentnost celého procesu revitalizace a hovoří o „nejasném požehnání“ (angl. mixed blessing). Žijí v regenerovaných či gentrifikovaných sousedstvích se směsicí dobrých pocitů ze zlepšení adresy a vnímají přitom, že jako nezamýšlený důsledek možná jejich vlastní snahy o zlepšení okolí se tyto kvality nakonec stanou pro ně samotné finančně nedostupnými, že oni sami pro ně přestávají být „dost dobřri““ (Neyden et al 2006).

\section{Shrnutí}

V tomto př́spěvku jsme se snažily nabídnout stručný úvod $\mathrm{k}$ diskusi o stárnutí $\mathrm{v}$ urbanizovaném prostoru. Argumentovaly jsme, že i když většina seniorů žije ve městech, nejsou města vždy tím věku-nejprátelštějším prostředím. Významnou roli přitom hraje snaha vnést do městského prostoru dynamické, oživující prvky, které jsou ale z vlastní definice a priori ageistické a nesou v sobě třídně konfliktní podtext. Jestliže hovoříme o revitalizaci jako procesu „obnovy“ a „očištění“, musíme se ptát, kdo, co, pro koho a jak sociálně konstruuje, co je potřeba očistit, jaké funkce jsou považovány za vhodné a jaké ne, co znamená dualita „nevhodné a starší“ vs. „,soudobé a funkčni“" a jaké jsou další souvislosti tohoto implicitně normativního př́stupu k prostoru a jeho „zlepšováni““. Na tyto otázky musíme hledat odpověd’ vždy, když se zajímáme obecněji o problematiku sociální inkluze, věkové diskriminace a ageismu. Prostředí sousedství, městské části či celého města/obce, ve kterém senior žije, v tomto zkoumání nabývá na velké důležitosti (Hagestad, Uhlenberg 2005). Veřejný prostor často obsahuje řadu bariér pro realizaci aktivního životního stylu a tyto bariéry, stejně jako samotný prostor, mohou mít jak formu fyzickou (schody bez zábradlí, nedostatek odpočinkových míst/laviček, špatná údržba v zimním období, nevyhovující povrchy, bariéry způsobené 
parkujícími auty nebo nedostupnost veřejných záchodků), tak i formu symbolickou, jejímž typickými a zdokumentovanými prríklady jsou např. obava z nočního vycházení z domu kvůli (subjektivnímu) riziku viktimizace, obtěžování vlastníky nebo potenciálními kupci apod. (Kuchařová 2002; Vidovićová, Gregorová 2008). Domníváme se proto, že je nutné $\mathrm{v}$ případě (nejen) staršího obyvatelstva věnovat pozornost rizikovým faktorům vzniku bariér a sociální exkluze, jejímiž zdroji může být úpadek a ztráty především obytných funkcí některých území, v post-socialistických zemích typicky soustředěných do centrálních částí měst (Haase, Steinführer 2009; Novotná 2008) anebo právě dynamické změny fyzického prostředí $\mathrm{v}$ důsledku relativně rychlé a překotné revitalizace tamtéž. Jak věříme, další a hlubší porozumění vzájemným souvislostem tvorby prožitku stárnutí a prožitku prostoru přispěje významnou měrou k formování věku-přátelských měst, ale i celých společností „pro všechny generace“.

\section{Literatura}

Bydlení senioru-syndikovaná studie. Ministerstvo pro místní rozvoj ČR. (Zpráva z výzkumu). Praha : Factum Invenio, 2008.

ABZ Slovnik cizich slov. Heslo gentrifikace [online]. [cit 2009-04-25]. Dostupné na www: <http://slovnik-cizich-slov.abz.cz/web.php/slovo/gentrifikace> .

ATKINSON, Rowland ; BRIDGE, Gary (eds.) Gentrification in a Global Context. Oxon : Routledge, 2005. 320 s. ISBN 0-41532-951-5.

ATKINSON, Rowland. Measuring gentrification and displacement in Greater London. Urban Studies, 2000, roč. 37, č. 1, s. 149 - 165. ISSN 0042-0980.

BALTES, Paul B. ; BALTES, Margret M. Successful aging : Perspectives from the behavioral sciences. Cambridge : Cambridge University Press, 1990. 416 s. ISBN 0-52143-582-X.

BELL, Paul ; GREENE, Thomas ; FISHER, Jeffery ; BAUM, Andrew. Environmental Psychology. 5. vyd. Oralndo,FL : Hartcourt College Publishers, 2001. 654 s. ISBN 0-80586-088-6.

BURJANEK, Aleš. Problémy bydleni optikou sociologie města. Brno : FF MU, 1995.

BUTLER, Tim. Gentrification. In BUCK, N.H., GORDON, I., HARDING, A., TUROK, I. (eds.). Changing Cities : Rethinking Urban Competitiveness, Cohesion, and Governance. Basingstoke : Palgrave, Macmillan, 2005. s. $172-187$.

DOUGLAS, Mary. The Idea of a Home : A kind of Space. Social Research, 1991, roč. 58, č. 1, s. 287 - 307. ISSN 0037-783X.

DVOŘÁKOVÁ, Nina. Senioři v centru Prahy. Praha : UK, Přírodovědecká fakulta, Katedra sociální geografie a regionálního rozvoje, 2008. 120 s. [Diplomová práce].

FOKKEMA, Tinekke ; GIERVELD, Jenny ; NIJKAMP, Peter. Big Cities, Big Problems : Reason for Elderly to Move? Urban Studies, 1996, roč. 43, č. 1, s. 353 - 377. ISSN 0042-0980.

GIDDENS, Anthony. Sociologie. 1. vyd. Praha : Argo, 1999. 595 s. ISBN 80-72031-24-4.

GILlEARD, Chris ; HIGGS, Paul. The Cultures of Ageing : Self, Citizen and the Body. 1. vyd. Essen : Perason Education, 2000. 219 s. ISBN 0582356415.

GLASS, Ruth. London: Aspects of Change. London : MacGibbon \& Kee, 1964. $342 \mathrm{~s}$.

Global age friendly cities. A Guide. [online]. 2007. [cit. 2010-06-07].Dostupné na www. <www.who.int/ ageing/.../Global_age_friendly_cities_Guide_English.pdf $>$.

GOLANT, Stephen M. Conceptualizing Time and Behaviour in Environmental Gerontology : A Pair of Old Issues Deserving New Thought. The Gerontologist, 2003, roč. 43, č. 5, s. $638-648$. ISSN 0016-9013. 
GREGOROVÁ, Eva ; VIDOVIĆOVÁ, Lucie ; KARCHŇÁKOVÁ, Kateřina. Regionální a teritoriální diferencovanost stárnutí v environmentálně-gerontologickém pohledu. 40. konference České demografické společnosti „Dvacet let sociodemografické transformace.“ Brno, 27 - 28. květen 2010.

GUBRIUM, Jay, F. Living and Dying at Murray Manor. Charlottesville : University Press of Virginia, 1997. 221 s. ISBN 0-81391-777-8.

HAASE, Annegret ; STEINFÜHRER, Annett. New Life in Old Houses. Silent Residential Change in the Postsocialist Inner City. [online]. 2009. [cit. 2010-06-07]. Dostupné na www: <http://www.evropskemesto.cz/cms/index.php?option=com_content\&task=view\&id=580\&Itemid=32>.

HAGESTAD, Gunhilde ; UHLENBERG, Perer. Social separation of Old and Young. Journal of Social Isuess, 2005, roč. 61, č. 2, s. 343 - 360. ISSN 0022-4537.

HENIG, Jeffrey R. Gentrification and Displacement of the Elderly : An Empirical Analysis. The Gerontologist, 1981, roč. 21, č. 1, s. 67 - 75. ISSN 0016-9013.

CHUDACOFF, Howard P. How Old are You? Age Consciousness in American Culture. Princeton, NJ : Princeton UP, 1989. 232 s. ISBN 0-69104-768-5.

Chui, Ernest. Ageing in Place in Hong Kong-Challenges and Opportunities in a Capitalist Chinese City. Ageing International, 2008, roč. 32, č. 3, s. 167 - 182. ISSN 0163-5158.

KUCHAŘOVÁ, Věra. Život ve stárí. Zpráva o výsledcich empirického šetření. Praha : SOCIOKLUB-VÚPSV. 2002. $89 \mathrm{~s}$.

LAWTON, Powell M. Environmental Proactivity and Affect in Older People. In SPACAPAN, A., OSKAMP, S. (eds.). Social Psychology of Aging. Newbury Park, CA : Sage, 1989, s. 135 - 164.

LEVY, Becca R. Mind Matters : Cognitive and Physical Effects of Ageing Self-Stereotypes. Journal of Gerontology: Psychological science, 2003, roč. 58, série B, s. 203 -211. ISSN 1079-5014.

McDONALD, Scott. Does Gentrification Affect Crime Rates? Crime and Justice, 1986, roč. 8, č. 1, s. 163 - 201. ISSN 0192-3234.

MIKESZOVÁ, Martina. Jak se lidé stěhují v rámci České republiky aneb vnitřní migrace v České republice ve srovnání s jinými evropskými zeměmi. Socioweb [online]. 2006. [cit. 2010-06-07]. Dostupné na www: <http://www.socioweb.cz/index.php?disp=teorie\&shw=231\&lst=106>.

MIKESZOVÁ, Martina ; LUX, Martin ; MORRISSEAU, Anne. Potenciální finanční nedostupnost nájemního bydlení po deregulaci nájemního-regionální perspektiva. Sociologický časopis/Czech Sociological Review, 2009, roč. 45, č. 2 , s. 315 - 343. ISSN 0038-0288.

NEŠPOROVÁ, Olga ; SVOBODOVÁ, Kamila ; VIDOVIĆOVÁ, Lucie. Zajištění potřeb seniorů s dưrazem na roli nestátního sektoru [on-line]. 2008. [cit. 2010-04-02]. Dostupné z www: <http://praha. vupsv.cz/Fulltext/vz_260.pdf>.

NEWMAN, Kathe ; WYLY, Elvin. The Right to Stay Put, Revisited : Gentrification and Resistance to Displacement in New York City. Urban Studies, 2006, roč. 43, č. 1, s. 23 - 57. ISSN 0042-0980.

NOVOTNÁ, Hana. Faktorová ekologie Brna v roce 2001. Změny ve vnitřni socioekonomické diferencicaci města mezi censy 1991 a 2001. Brno : Masarykova univerzita. Př́rodovědecká fakulta, 2008. [Rigorózní práce].

NYDEN, Philip ; EDLYNN, Emily ; DAVIS, JulieThe Differential Impact Of Gentrification On Communities In Chicago [on-line]. 2006. [cit. 2010-04-02]. Dostupné na www: <http://www.luc.edu/curl/ pdfs/HRC_Report.pdf>.

OSWALD, Frank ; WAHL, Hans-Werner ; SCHILLING, Oliver ; NYGREN, Carita ; FÄNGE, Agneta ; SIXSMITH, Andrew ; SIXSMITH, Judith ; SZÉMAN, Zsuzsa ; TOMSONE, Signe ; IWARSSON, Susanne. Realationships Between Housing and Healthy Aging in Very Old Age. The Gerontologist, 2007, roč. 47, č. 1, s. 96 - 107. ISSN 0016-9013.

OSWALD, Frank ; WAHL, Hans-Werner ; MARTIN, Mike ; MOLLENKOPF, Heidrun. Toward Measuring Proactivity in Person-Environment Transactions in Late Adulthood : The Housing-Related 
Control Beliefs Questionnaire. Journal of Housing for the Elderly, 2003, roč. 17, č. 1-2, s. 135 - 152. ISSN 0276-3893.

PHILLIPSON, Chris. The „Elected“ and the „Excluded“: Sociological Perspectives on the Experience of Place and Community in Old Age. Ageing and Society, 2007, roč. 27, č. 3, s. $321-342$. ISSN 0144-686X.

REDFOOT, Donald. On the Separatin'Place : Social Class and Relocation Among Older Women. Social Forces, 1987, roč. 66, č. 2, s. 486 - 500. ISSN 0037-7732.

SCHARF, Thomas ; PHILLIPSON, Chris ; SMITH, Allison. Multiple Exclusion and Quality of Life amongst Excluded Older People in Disadvataged Neighbourhoods. London : Office of the Deputy Prime Minister, 2005. 47 s.

SINGELAKIS, Andrew T. Real Estate Market Trends and the Displacement of the Aged : Examinaion of the Linkages in Manhattan. The Gerontologist, 1990, roč. 30, č. 5, s. 658 - 666. ISSN 0016-9013.

SMITH, Allison, E. Ageing in Urban Neighbourhoods. Place Attachment and Social Exclusion. Bristol : The Policy Press, 2009. 242 s. ISBN 978-1-84742-270-5.

SMITH, Neil ; WILLIAMS, Peter (eds.). Gentrification of the City. Boston : Alen and Unwin, 1986. 160 s. ISBN 0-04301-202-7.

SOCHŮRKOVÁ, Iva. Migrace obyvatelstva v Jihomoravském kraji s di̊razem na obdobi po roce 1989. Brno : Přrírodovědecká fakulta MU, Geografický ústav, 2006. [Bakalářská práce].

STEINFÜHRER, Annett. Sociálně prostorové struktury mezi setrvalostí a změnou. Historický a současný pohled na Brno. Sociologický časopis, 2003, roč. 39, č. 2, s. 169 - 192. ISSN 0038-0288.

SUNEGA, Petr. Představy o budoucím stěhování, ideálním bydlení. [online]. 2001. [cit. 2010-04-02]. Dostupné na www: <http://seb.soc.cas.cz/postoje2001/prezentace/seb_sunega_idealnibydleni.pdf>.

SÝKORA, Luděk. Gentrification in post-communist cities. In ATKINSON, R., BRIDGE, G. (eds.) Gentrification in a Global Context. Oxon : Routledge, 2005, s. 91 - 106. ISBN 0-41532-951-5.

SÝKOROVÁ, Dana. Autonomie ve stárí. Kapitoly z gerontosociologie. 1. vyd. Praha : Sociologické nakladatelství, 2007. 284 s. ISBN 978-80-86429-62-5.

SÝKOROVÁ, Dana. Prostor a věci v kontextu stáŕí. Sociologický časopis/Czech Sociological Review, 2008, roč. 44, č. 2, s. $401-421$. ISSN 0038-0288.

ŠILHÁNKOVÁ, Vladimíra. Revitalizace centrálních částí měst. Urbanismus a územní rozvoj, 2000, roč. 3, č. 3, s. 2 - 6. ISSN 1212-0855.

TEMELOVÁ, Jana. Jak architektura kompletně změnila obraz Anděla. Stavebni fórum [online]. 2006. [cit. 2009-23-4]. Dostupné na www: <http://www.stavebni-forum.cz/data/cms/7334/pdf/1-jak-architektura-kompletne-zmenila-obraz-andela-iii.pdf $>$.

THOMPSON, Michael. The Gentrification of the Labor Party. Sydney : Pluto Press, 1999. 118 s. ISBN 1-86403-073-9.

VAISHAR, Antonín a kol. Současný vývoj vnitřnich částí Brna a Ostravy. Ústav Geoniky, AV ČR, 2009. 136 s. ISBN 978-80-86407-69-2.

VIDOVIĆOVÁ, Lucie ; GREGOROVÁ, Eva. „My jsme si stáři nezavinili, to čeká každýho“... Povaha a prevence diskriminace seniorů v České republice. Praha : Život 90, 2008. 91 s. ISBN 978-80-254-3808-4.

VIDOVIĆOVÁ, Lucie. Stárnutí, věk a diskriminace : nové souvislosti. 1. vyd. Brno : Masrykova univerzita, 2008. 233 s. ISBN 978-80-210-4627-6.

VIDOVIĆOVÁ, Lucie ; RABUŠIC, Ladislav. Senioři a sociální opatření v oblasti stárnutí v pohledu české veřejnosti. Zpráva z empirického výzkumu. Praha : VÚPSV, 2003. 67 s.

WAPNER, Seymour. A Holistic, Developmental, System-Oriented Environmental Psychology : Some Beginings. In STOKOLS, D., ALTMAN, I. (eds.) Handbook of environmnetal psychology. New York : Wiley, 1987, s. 1433 - 1465. ISBN 0-47163-017-9. 
ZUKIN, Sharon. Gentrification : Culture and Captial in the Urban Core. Annual Review of Sociology, 1987, roč. 13, s. 129 - 147. ISSN 0360-0572.

\section{Autorky}

Lucie Vidovićová je absolventkou FSS MU, kde pracuje jako socioložka a výzkumná pracovnice. Věnuje se sociologii stárnutí, věkové diskriminaci, postojům vůčí stárnutí, otázkám aktivního stárnutí a věkovému mainstreamingu.

Kontakt: Lucie.Vidovic@seznam.cz

Eva Gregorová je absolventkou oboru sociologie FSS MU se specializací na sociálně-urbanistická studia. V minulosti spolupracovala na projektu VÚPSV týkajícím se věkového mainstreamingu a jako výzkumná pracovnice FSS MU spolupracovala na projektu o věkové diskriminaci a ageismu. V současné době pracuje jako socioložka na Magistrátu města Brna v Kanceláři strategie města, kde koordinuje a usměrňuje odborné práce v oblasti sociologie a spolupracuje na tvorbě jednotlivých rozvojových a koncepčních dokumentů města.

Kontakt: gregorova.eva@brno.cz 